[11] Rouse, M. (2008). Developing Inclusive Practice: A Role for Teachers and Teacher Education? Education in the North, 16. Available at: http://www.abdn.ac.uk/eitn/journal/46/

[12] Avramidis, E., Bayliss, P. Burden, R. (2000). A Survey into Mainstream Teachers' Attitudes Towards the Inclusion of Children with Special Educational Needs in the Ordinary School in one Local Education Authority. Educational Psychology, 20 (2), 192-211. doi: http://doi.org/10.1080/713663717

\title{
CHARACTERISTICS OF PEDAGOGICAL CONDITIONS OF RESPONSIBLE ATTITUDE TOWARDS STUDENTS' FUTURE PROFESSION FORMATION IN PEDAGOGICAL UNIVERSITIES
}

\author{
Kateryna Zhytnukhina \\ Primary Education Department \\ Pavlo Tychyna Uman State Pedagogical University \\ 2 Sadova str., Uman, Ukraine, 20300
}

\begin{abstract}
The article gives characteristics of pedagogical conditions of responsible attitude towards students' future profession formation in pedagogical universities based on the analysis of scientific sources and empirical material:

1) purposeful motivation, awareness of the need for the formation of the specified quality as the future teacher's spiritual value (motivational-value component of a responsible attitude to the future profession formation);

2) improvement of students' educational and non-auditing activities content in pedagogical universities (cognitive component);

3) organization of student activity on the implementation of responsible organizational and teaching assignments (operational and activity component).

It is substantiated that the second pedagogical condition is realized by deepening the future teachers' educational professional training disciplines content (classroom educational activity) as educational material of the given direction in order to master professional duty requirements; students' non-auditing educational activities through the circle "Pedagogical Volunteering" functioning. It is indicated that the third pedagogical condition is realized by the way of: student self-government, aimed at organizing various educational activities for the purpose of multi-role execution of responsible orders by the students, modern methods of using future teachers' self-education on a reflection basis; application of interactive forms and methods in extra-curriculum educational work; organization of managerial interaction between the practice organizers at different levels and educational institutions in order to monitor the formation of a responsible attitude towards students' future profession.However, only the harmonization of the general pedagogical conditions will be a prerequisite for the effective formation of a responsible attitude towards the students' future profession in pedagogical universities.
\end{abstract}

Keywords: pedagogical conditions, future teachers, responsible attitude towards future profession, students' education in pedagogical universities.

\section{Introduction}

Modern society is characterized by a polarity of values and inconsistency of social requirements with their observance in various spheres of Ukrainian activity: irresponsibility in professional duties performance has been massively stated, despite the fact that in the second paragraph of the updated version of the current Law of Ukraine "On Education", the purpose of education is defined as "... the education of responsible citizens who are capable of conscious social choice and directing their activities in favor of other people and society..." [1]. In the same document, the same indicators of the fifth and sixth levels of the National Qualifications Framework establish the ability of a person to "be responsible for the results of his activity and control other people in certain situations" [1]. Responsibility for rules observance and professional duties fulfillment is an actual problem of our country's Ukraine's present not only in the context of specified Law observance, but 
also in the formation of specified quality citizens taking into account constantly changing social conditions in the education sector.

Scientific studies analyze aspect of the problem of formation of the responsible attitude to the future profession: responsibility in students of military institutions [2], pedagogical responsibility in students of a pedagogical college [3] and so on. Some papers are dedicated to the problems of a responsible attitude formation towards paternity in the field of social pedagogy, theory and methodology of education: the students of the classical university in the process of extracurricular educational work [4]. Researchers note that responsible attitude formation as a personality's quality of a student "is achieved in the conditions of forming the responsibility motivation and positive responsible behavior habits" [2, p. 162-163]. However, the purposeful study of the problem of forming a responsible attitude towards students' future profession in pedagogical universities has still not been implemented.

\section{Aim of research}

The aim of the article is to describe the pedagogical conditions for the formation of a responsible attitude towards the future profession among students of pedagogical universities on the basis of scientific sources and empirical material analysis.

\section{Materials and Methods}

In scientific studies, traditionally, pedagogical conditions as factors of the effectiveness of a certain educational process are determined in two ways: on the basis of the scientific sources analysis of the under study problem and based on the results of an experimental (pilot) study. By reaching the goal of this study phase, combine both ways, using the results of the above mentioned scientific papers.

First of all, we will analyze the essence understanding of the concepts of "responsibility" and "pedagogical responsibility" by researchers. Thus, scientists understand the investigated concept as:

- complex, integral professional quality of the person whose psychological-pedagogical structure includes a set of intellectual, volitional and emotional components [2, p. 162];

- a steady inner, conscious personal quality, based on the "personality awareness of his own life choice and the willingness to perform tasks connected with the future independently..." [4, p. 14];

- system-building professional quality is awareness of the need for fair compliance with the requirements and norms of a holistic educational process [3, p. 187];

- anticipate the behavior effects; be responsible for your own actions, taking into account the public assessment of the actions consequences [2, p. 162];

- the readiness of an individual to act in accordance with the requirements of professional duty on the basis of his/her deep awareness [2, p. 162];

- anticipate the results of professional activity and be responsible for it outside the external (society, colleagues, students and their parents) and internal authorities (sense of duty and conscience) [3, p. 187].

Thus, researchers characterize the concept of "professional responsibility" through the following key definitions: "quality", "position", "attitude", "ability" and "readiness" of personality. In our opinion, the definition of "teacher's responsible attitude to the future profession" is the consistent quality of student's personality at a pedagogical university regarding compliance with the established principles of further professional activity; is manifested in the ability and readiness, that is, professional competence, to perform certain professional and pedagogical actions, taking optimal and correct decisions, anticipating their possible consequences. Professional responsibility is always determined by strict adherence to the legal and regulatory framework of the specialist's activity sphere.

We are completely agree with the statement as to understanding the essence of the notion "forming the individual's responsibility": "purposeful, guided and multidimensional process of influence on the consciousness, feeling, will of the student's personality in order to transform subjective-personal values ... into the individual whole, bringing-up a set of persistent properties and qualities that are needed in the future ..." [4, p. 14]. 
It is the purposeful influence on the formation of individual's certain qualities that involve the observance of clear conditions for its effectiveness, in particular, in the process of preparing future teachers in pedagogical universities.

Swedish scientists consider the formation of pedagogical responsibility sense as an analogue to the professional identity formation. Researchers prove that the project of educational activities in higher educational institutions should contribute to a critical reflection of students' professional development, provide differentiated ways to stimulate the identification process with the teacher's future professional role [5]. We consider "professional identity" concept as a psychological structure component of "pedagogical responsibility" concept. This dependence needs to be investigated separately.

However, in order to take advantage of this potential, educational institutions must adhere to the highest standards. Future teacher training programs in higher educational institutions should be aimed at creating partnerships with schools, eliminating those university laws that do not contribute to investing in high-quality students' academic and practical training. This will contribute to the formation of the future teachers' professional responsibility [6]. Call these conditions the "higher order" of future teacher training and at the same time "the best chance for a sharp improvement in educational opportunities in the United States" [6]. As we see, the problem of responsible attitude formation towards the future profession among students in a pedagogical university is not only relevant and global, but also has a clearly expressed individual character with respect to a particular country. However, the common feature of this process is to emphasize the quality of future teachers' training.

The researchers are also convinced that future teachers' training assumes the following conditions:

1) the acquisition of a comprehensive system of knowledge, beliefs and assumptions about the teacher's profession;

2) acquisition of an affective experience comprehensive system in relation to the pedagogical profession;

3) the formation and manifestation of appropriate behavior in accordance with observations and affective emotions.

According to the obtained statistical data, the greatest obstacles occur in the process of implementing the third pedagogical condition and at the integration level with other conditions [7]. However, behavioral attitudes towards the profession can directly depend on the context and individual subjective experience identified by the relative professional context.

A positive attitude towards vocational training is a priority of any reform in the educational field. However, there are significant differences between the students-future teachers' attitude and the teachers-practitioners' attitude towards teaching and methodological training. Views cannot be measured directly. Indirect methods, less systematized, operate through social mechanisms. The author has offered influence models on positive attitude formation to the chosen profession as a starting point in the educational situations planning. In this case, the motivation in student behavior is meaningful only in relation to certain values. Effective educational model, oriented on authentic values, is characterized by the fact that the trainers-educators' activity is a model of a professional situation itself [8]. Thus, two conditions for responsible attitude formation towards the teacher's professional activity are actualized: value attitudes towards the future profession and the appropriate selection of mentor teachers as models of professional conduct.

Professionally relevant personal qualities are special quality of future teacher's personality. The research of Kazakh scholars outlines the theoretical basis for non-extracurricular students' studies as one of the subsystems of the educational process in the pedagogical university, future teachers' professional, personal and self-development on the basis of individual creativity. The theoretical model of professional pedagogical education subsystem at the university is developed, which includes the target set of entrants, subjects' peculiarities of the educational process (students $\leftrightarrow$ university teachers $\leftrightarrow$ curators $\leftrightarrow$ administration), educational technologies [9]. Thus, if in the previous study the quintessence of a responsible attitude to professional activity formation is chosen as a pedagogical educational practice model, then Kazakh scientists are 
convinced in the need for teachers' exemplary work and the functioning of the model during the classroom extracurricular work.

For our study, it is important to compare the process of shaping future psychologists' sense of responsibility, given the significant psychological component in the structure of future teacher's activity and the psychological nature of "responsible attitude" concept.

In the process of studying future psychologists' professional formation peculiarities, scientists have established the individual character of pre-professional formation, and the formation of professional responsibility at various stages of preparation. In the context of professional responsibility, emphasis is placed on the future specialist's personal responsibility. Therefore, the future specialist psychologist must have an adequate self-esteem; understand the individual peculiarities of his/her own personality; skills, strengths and weaknesses of the character. It is useful to know and be able to apply methods of compensating for their shortcomings. Thus, psychologist's professional and personal qualities should be a high level of self-acceptance; the ability to accept the reality, the desire for self-development, etc. [10]. The role of schools in the future is radically transformed, remains uncertain. All methods are for individual use. Obviously, the future is by education as a global network of learning: dominant and comprehensive [11]. Possibilities of psychosocial pedagogical study analysis and its work modes help to improve the processes of their assessment, and also allow to determine how the institutional, economic, social, material and political conditions that are an integral part of the process of creating knowledge and forming its internal structure, interact to enhance professional teaching [12]. Thus, in the process of distinguishing pedagogical conditions for responsible attitude formation towards students' professional activity in pedagogical universities, it is necessary to take into account the current trends in future teachers' professional training; psychological component of this process and pedagogical activity in particular; use a spectrum of psychosocial research techniques; take into account global and local trends in education.

The analysis of recent dissertations allowed to state that scientists distinguish pedagogical conditions of forming future employees' sense of responsibility in different fields according to the three main components of their professional readiness:

1. Motivational value:

- purposeful positive motivation and teaching of the need for the specified quality formation [4, p. 15];

- value conscious, emotional attitude to the assimilation of the professional duty requirements [2, p. 164].

2. Cognitive:

- assimilation of professional duty requirements [2, p. 163-164];

- content improvement of the future professionals' training by moral and ethical content

[3, p. 188], through the implementation of a special club program [4, p. 15-16].

3. Operational activity:

- at the teachers' level:

- practice expansion of fulfilling the responsible orders by the students as performers, organizers, and leaders in various activities [2, p. 164; 3, p. 188];

- raising the teacher's culture / teaching skills, arming them with methods of forming responsibility [2, p. 164];

- the use of interactive forms and methods in extra-curricular educational work [4, p. 16];

- creation of a developing reflexive environment [3, p. 188];

- providing managerial interaction between: teachers and students' self-management [4, p. 16];

- at the students' level:

- expansion of student autonomy in various activities [2, p. 164];

- raising the role of student groups in shaping responsible dependence relations [2, p. 164];

- self-upbringing of responsibility among students [2, p. 164].

Thus, the pedagogical conditions for the formation of future specialists' responsible attitude in the context of the first component of readiness for professional activity - motivational and value - 
are defined by the scientists as a positive motivation, upbringing of the corresponding need and a valuable awareness of the need to be responsible, to form this personal quality. In the context of the second component of readiness - cognitive - the researchers are unanimous in the fact that the content of training specialists in relation to the isolated problem and the skills acquired by future specialists should be improved.

We are drawing attention to the fact that the pedagogical conditions for the formation of future specialists' responsible attitude in the context of the third component of readiness for professional activity - operational activity - are distributed on two other levels: the level of teachers and students. Moreover, scientific sources do not indicate such a division, but it is determined by us according to the actual direction. In the first case (at the teacher's level) we are talking about: emphasizing on the role of improving the production practice and expanding the experience of fulfilling tasks by students, improving teachers' pedagogical culture and mastery, using interactive forms and methods in extra-curricular educational work, ensuring managerial interaction between the participants and co-organizers of the educational process. In the second one (at the students' level) it is about the expansion of students' autonomy, increasing the role of student groups and self-education.

\section{Result}

Thus, based on the analysis of scientific sources [2-4] and empirical material, we have identified such pedagogical conditions for forming a responsible attitude towards the future profession among students of pedagogical universities:

1. Purposeful motivation, awareness of the need for the formation of the specified quality as the future teacher's spiritual value (motivational value component of responsible attitude to the future profession formation).

2. Improvement of the content of students' educational and non-auditing activities in pedagogical universities (cognitive component):

- future teachers' vocational training (classroom educational activities) by deepening the contents of educational disciplines with educational material of the indicated direction in order to assimilate the requirements of professional duty;

- students' non-auditing educational activities through the functioning of the "Pedagogical Volunteering" circle.

3. Organization of students' activities on the implementation of responsible organizational and educational tasks (operational and activity component) through:

- student self-government, aimed at organizing various educational activities for the purpose of students' multi-role execution of responsible orders, the use of modern methods of future teachers' self-education on a reflection basis;

- application of interactive forms and methods in extra-curriculum educational work;

- organization of managerial interaction between the practice organizers at different levels and educational institutions in order to monitor the formation of a responsible attitude towards students' future profession (Fig. 1).

We will describe the mentioned pedagogical conditions in detail.

Thus, the implementation of the first pedagogical condition will ensure conducting of explanatory and diagnostic work with students. Such work should orient students, first of all, to understanding causal relationships on the principle: "duty/rule $\rightarrow$ non-compliance/violation $\rightarrow$ problem/punishment."The methods of such educational work at the stage of explanation may be: individual, group and mass conversations, lectures, demonstration of practical examples with the use of video presentations (video-scenes), disputes, movie viewing, reader conferences, discussion of media scenes on resonant pedagogical situations etc. At the diagnostic stage, questionnaires, testing, solving pedagogical situations will be relevant. In the process of diagnosis, it is necessary to monitor the change dynamics of emotional attitude towards pedagogical situations that will be analyzed. It is also necessary to spend hours of communication on the topics: "Responsibility in the structure of teacher's personality", "Teacher's professional responsibility is the responsibility for students' life and health", etc. 


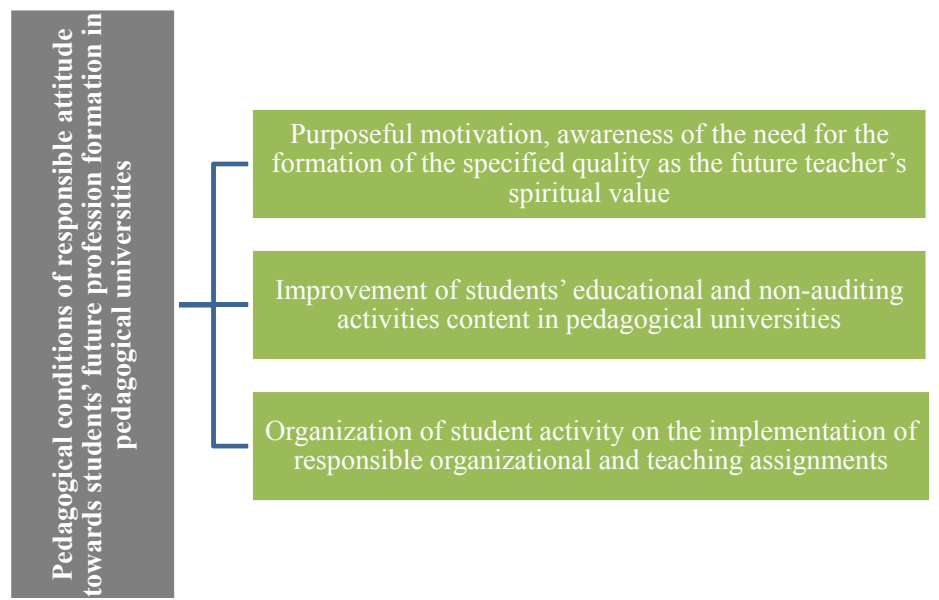

Fig. 1. Pedagogical conditions of responsible attitude towards students' future profession formation in pedagogical universities

Regarding the analysis of pedagogical situations, the teacher's task is to organize a comparative analysis of irresponsible and competent teachers' actions in similar situations. It is appropriate to carry out a well-balanced selection of pedagogical situations in order to make students aware of the consequences of irresponsible attitudes towards professional duties. For example, to analyze several situations in which a teacher leaves unacknowledged pupils during a lesson, with examples of the consequences of such a safe attitude to performing professional duties (pupils' fights with traumatic consequences, escapes from school because of the conflict with classmates in the absence of a teacher, etc.). As a positive example, you can propose to review the interview record of students whose teacher never leaves unattended pupils in the classroom.

At the same time, the first pedagogical condition for the formation of a responsible attitude towards the future profession among students of pedagogical universities should be realized at all times, and not only at the beginning of the experimental study, since the attitude has an emotional subtext and may be unstable.

The implementation of the second pedagogical condition, which is the improvement of students' educational and non-auditing activities content in pedagogical universities, has two directions: deepening the educational material contents of educational disciplines in order to master the requirements of professional duties and the functioning of "Pedagogical volunteering"circle. Description of the disciplines contents deepening should be written in detail in a separate publication. Instead, we will briefly describe the essence of the "Pedagogical volunteering"circle functioning.

This form of out-of-school educational work with students has proven to be quite effective, as any modern form of volunteer activity. Its purpose is to gather students around the practical problems solution of their future professional activities in extracurricular time. Future teachers are encouraged to become attached as a volunteer assistant to a teacher-practitioner in the school where the pedagogical practice has been passed (without the practice evaluation and confirmation - voluntarily). Teacher-instructor defines a range of tasks to be performed by a volunteer student. For example, to conduct an individual conversation with a disobedient pupil; provide tuition to students who don't cope with the training; to neutralize the conflict arisen between students in communication, etc. Formation of a responsible attitude to the future profession among students of pedagogical universities in this case contributes to the emphasis on the future teachers' independence and result reflection. The effect of the "choice freedom" of the teacher-tutor, the tasks and the lack of result evaluation contribute to the future teachers' self-realization, the formation of autonomy, mobility and responsibility for the work done. Students outside the framework of pedagogical practice, limited by content and requirements of the curriculum, take an active part in the educational process of general secondary education institutions. They acquire the ability to assume responsibility for the decision taken in the pedagogical situation and its consequences.This enables students to try themselves in the future profession, directly feeling 
the responsibility of a trusted teacher-tutor, without a traditional report for work in front of the university teachers. According to the results of the students' survey in pedagogical universities, this situation doubles the responsible attitude to fulfilled duties, since there is no direct control by the teachers (the previously mentioned effect of "choice freedom").Currently, organizational skills and abilities are being improved through the constant need for organizing unplanned pedagogical activities (meetings with students' parents, organization of excursions, etc.). Thus, students of pedagogical universities are realized as individuals, learn to identify problems, set pedagogical tasks for themselves and solve them.

The content of the program "Pedagogical volunteering" includes a weekly compulsory students-teacher discussion of pedagogical situations and the work results done in the process of volunteer-pedagogical activity.The classic style of discussion is the "aquarium" method: the participants sit in a circle; in the center of the circle is a speaker, who talks in detail about a pedagogical situation. It is clear that each day of educational volunteering is full of pedagogical situations. However, discussing them all is impossible. Therefore, it is expedient to offer students a choice of one of them (the most important, in their opinion). Students who sit around listen carefully to the speaker, who not only describes the course of the educational situation with the decision, but also critically assesses his own actions. A compulsory stage of such a discussion is:

- self-correlation of the future teacher-speaker's actions with professional requirements and regulatory documents, tangible pedagogical activities;

- self-simulation of the situation according to the algorithm: "making the wrong decision $\rightarrow$ negative consequence $\rightarrow$ teacher's responsibility".

The next stage is the expression of opinions by the group of "listeners" regarding the analyzed situation. Key questions: "Did a colleague do a right thing? What student-volunteer actions can be called irresponsible and why? What negative consequences could have such actions? What student-volunteer actions can be called responsible and why? What is the normative and legal basis for the colleague's responsible actions?"Extremely valuable, from a practical point of view, is the invitation of the teacher-practitioner on such a discussion, in particular, if it's a participant of the analyzed pedagogical situation.

Thus, the implementation of the third pedagogical condition for the formation of a responsible attitude towards students' professional activity in pedagogical universities - the organization of students' activities on the implementation of responsible organizational and teaching assignments - is carried out through the functioning of the scientific and practical student group "Pedagogical volunteering".The activity of such a circle a priori involves the instruction of student self-government:the organization of various educational activities planned by the student's assets of the university, it is recommended to be coordinated with the action plan of "Pedagogical volunteering" circle for the purpose of multi-role execution of responsible orders by students. It is advisable to carry out an analysis of the educational activities carried out by the "aquarium" method with the aim of self-educating future teachers on a reflective basis.

The interactive forms and methods application of teaching in extra-curricular educational work plays a significant practical role in shaping the responsible attitude towards the students' professional activity in pedagogical universities.They may be alternatives to the "aquarium" method in the process of discussing pedagogical situations with student volunteers. These methods are popular in recent years: disputes, problem discussions, information dialogues (comparisons with similar situations covered in the media), thematic seminars/conferences, role-playing games, case study, trainings, coaching, educational projects defense, "Microphone/Microphone for two", "Associative bush", "Brainstorming in pairs", etc.

Important in this context is the organization of managerial interaction between the practice organizers at different levels and educational institutions in which: students pass the pedagogical practice provided by the curriculum; there is a circle "Pedagogical volunteering" functioning; future teachers can work potentially. Such an organization is planned to monitor the formation of students' responsible attitude towards the future profession. The specified monitoring is carried out by questioning, interviewing, and testing general secondary education institutions administration, teachers-mentors and other participants of the educational process. 
It should be noted that only the interconnected observance of the three distinct conditions will be a guarantee of the high level formation of responsible attitude towards the future profession among students in pedagogical universities.

However, further scientific research requires a problem of development and experimental verification of the methodology for the implementation of pedagogical conditions for the formation of a responsible attitude towards the future profession among students in pedagogical universities.

\section{Conclusion}

1. So, we have given pedagogical conditions of responsible attitude towards students' future profession formation in pedagogical universities based on the analysis of scientific sources and empirical material:

1) purposeful motivation, awareness of the need for the formation of the specified quality as the future teacher's spiritual value (motivational value component of a responsible attitude to the future profession formation);

2) improvement of students' educational and non-auditing activities content in pedagogical universities (cognitive component);

3) organization of student activity on the implementation of responsible organizational and teaching assignments (operational activity component).

2. Only the harmonization of the general pedagogical conditions will be a prerequisite for the effective formation of a responsible attitude towards the future profession among students in pedagogical universities.

\section{References}

[1] Pro osvitu (2017). Zakon Ukrainy. 05.09.2017. No. 2145-VIII. Available at: http://zakon0.rada. gov.ua/laws/show/2145-19

[2] Hamula, I. A. (2002). Formuvannia vidpovidalnosti v kursantiv viiskovykh instytutiv. Kyiv, 202.

[3] Yurynets, O. O. (2010). Formuvannia pedahohichnoi vidpovidalnosti u studentiv pedkoledzhu. Lutsk, 275.

[4] Smalko, O. V. (2016). Formuvannia vidpovidalnoho stavlennia do batkivstva u studentiv klasychnoho universytetu v protsesi pozaaudytornoi vykhovnoi roboty. Uman, 20.

[5] Abrandt Dahlgren, M., Hammar Chiriac, E. (2009). Learning for professional life: Student teachers' and graduated teachers' views of learning, responsibility and collaboration. Teaching and Teacher Education: An International Journal of Research and Studies, 25 (8), 991-999. doi: http://doi.org/10.1016/ j.tate.2009.03.019

[6] Darling-Hammond, L. (2009). Teacher Education and the American Future. Journal of Teacher Education, 61 (1-2), 35-47. doi: http://doi.org/10.1177/0022487109348024

[7] Andronache, D., Bocos, M., Bocos, V., Macri, C. (2014). Attitude Towards Teaching Profession. Procedia - Social and Behavioral Sciences, 142, 628-632. doi: http://doi.org/10.1016/j.sbspro.2014.07.677

[8] Vali, I. (2015). Attitude towards Pedagogical and Methodological Training and Development A Comparative Analysis. Procedia - Social and Behavioral Sciences, 180, 820-827. doi: http://doi.org/10.1016/ j.sbspro.2015.02.217

[9] Tazhbayeva, S. G. (2015). Scientific Basis of the Future Teachers Extracurricular Activities Organization (Educational Aspect). Available at: https://articlekz.com/en/article/19607

[10] Assemgul, A., Moldazhanovaa, A., Amanovaa, A, Amanjol, A., Tashetova, A., Bissembaevab, K., Gulzhanar, K. (2016). Future Teacher-Psychologists' Professional Position as a Component of Professional Competence Formation. International Journal of Environmental \& Science Education, 11 (18), $12317-12325$.

[11] Scott, C. L. (2015). The futures of learning 3: what kind of Pedagogies for the 21st Century? Education research and foresight. Available at: http://unesdoc.unesco.org/images/0024/002431/243126e.pdf

[12] Sousa, C. P. de, Boas, L. P. S. V. (2012). Avaliacao da formacao de professores: uma perspectiva psicossocial. Cadernos de Pesquisa, 42 (147), 772-789. doi: http://doi.org/10.1590/s0100-15742012000300007 